\title{
A Identidade Nacional Revista nas Entrelinhas do Monumentalismo Étnico em Petrópolis.
}

\author{
Paola Dias ${ }^{1}$
}

\section{Resumo}

Este é um estudo exploratório que visa compreender o processo de formação de identidades na contemporaneidade a fim de constituir-se em elemento para a produção do formato final da dissertação de mestrado em Memória Social.

O objetivo geral deste trabalho é discutir a frágil construção de uma identidade nacional brasileira em meio à emergência e monumentalização das identidades étnicas no mundo globalizado. Seus objetivos específicos são: a) compreender a construção de uma narrativa que leva ao processo de identificação nacional em torno do consumo massificado de um produto industrializado, a cerveja, em contraponto à emergência de um outro tipo de narrativas que visam construir identidades étnicas, per se, fragmentárias, a partir da evocação de memórias que são objetivadas, também elas, em produtos para o consumo turístico de um público especializado; b) compreender o alcance empírico dessas proposições, tomando por objeto de investigação, a construção das identidades nacional e étnicas em contexto local.

A hipótese deste trabalho é de que em meio à crise dos Estados nacionais e, com isso, das identidades construídas em torno de unidades englobantes, novos projetos identitários se articularam em torno de uma

\footnotetext{
${ }^{1}$ Mestranda do PPGMS-UNIRIO. Projeto de dissertação: Esquecimento e negação da cultura negra: o remanescente de quilombo na memória da cidade imperial. Orientador: Prof. Dr. Javier Alejandro Liefschitz. Contatos. E-mail: paola.dias2013@bol.com.br; Cel: (21) 96677-4041
} 
complexa interseção entre a ressurgência de demandas étnicas e a emergência de novas demandas de consumo cultural, tornando possível a reorganização das identidades locais e nacionais, bem como a homogeneização das mesmas. Para isto, escolheu-se a cidade de Petrópolis e a problemática construção de sua identidade diante da unidade englobante, por um lado, e da fragmentação étnica, por outro.

Assim, são tomados por objetos de observação deste trabalho dois monumentos erigidos em torno da reorganização das memórias e das identidades nacional e étnica, respectivamente, a Festa de São Pedro de Alcântara e a Festa do Colono Alemão. Esta reorganização identitária implica numa escolha entre a auto identificação de Petrópolis como Cidade Imperial, ou como Colônia alemã.

A Festa de São Pedro de Alcântara, santo que fora designado pela Coroa para ser o primeiro padroeiro do país e que, após rejeitado pela população, fora designado para ser o padroeiro da cidade, manipula símbolos que remetem a uma memória incômoda para a nação que escolheu ser uma República Democrática e para a cidade que vivencia os custos materiais de manutenção da realeza. Sua festa rememora um projeto de imposição da posição de uma classe dominante ao conjunto da nação. Ela surge, desta forma, como exemplo do malogro na tentativa de se articular um elemento da identidade nacional à identidade local.

Já a Festa do Colono Alemão, manipula a imagem de um produto étnico que "espontaneamente" (espontaneidade construída por meio de múltiplas e massivas campanhas publicitárias) teria se transformado em símbolo de uma identidade nacional, da homogeneização de classes e de regiões do país em torno de um produto destinado ao consumo de massa. Esta festa surge, portanto, como o exemplo bem-sucedido da associação 
entre o étnico/local e o nacional que levaria, por fim, à reconciliação e homogeneização entre esses dois termos.

A fim de empreender a discussão, ora proposta, serão utilizados os seguintes autores/temáticas: Para o bloco de discussões sobre o processo de identificação e construção de memória, serão utilizados principalmente Tomás Tadeu da Silva (2011), Stuart Hall (2012) e Andreas Huyssen. Bloco que se integra àquele que discutirá as identidade nacionais (o qual se pautará principalmente pelas proposições de Barroso e Albrow), bem como ao bloco seguinte, que discutirá a tensão entre o global, o regional e o local, bem como a retração do papel dos Estados nacionais. Para este grupo de discussões - a globalização e as especificidades da contemporaneidade trazem-se os seguintes autores: Boaventura de Souza Santos, Otávio Ianni, Gilberto Velho e Zigmunt Baumann. Uma vez que este último aponta como uma das características da contemporaneidade a centralidade do consumo na organização das identidades, este autor servirá de elo para compreender a formação de uma cultura baseada no consumo de artefatos, fazendo uma ponte para o último bloco de discussões, baseadas, principalmente nas proposições de Pierre Bourdieu, Eric Hobsbauwm, George Yúdice e Néstor Canclini.

Palavras Chave: Monumentalismo, Identidade étnica, Globalização

\section{Referências}

ALMEIDA, C. [et alli]. Estudo Histórico Geográfico da Evolução administrativa do Município de Petrópolis e sua toponímia. $1^{o}$ Simpósio Brasileiro de Cartografia Histórica: passado presente nos velhos mapas conhecimento e poder. Paraty, RJ - 10 a 13 de maio de 2011. 
ALVES, C. F. São Pedro de Alcântara: padroeiro de Petrópolis e do Brasil. Disponível em: [http://www.catedraldepetropolis.org.br/] Acesso em: [01, jun, 2014].

AMBROZIO, J.C.G. O presente e o passado no processo urbano da cidade de Petrópolis. Uma história territorial. 2008. Tese de Doutorado. Universidade de São Paulo.

ANGELO, E. R. B. Percepções, Construções e Transformações na Cidade de Petrópolis, RJ. Anais do XXI Encontro Estadual de História da ANPUH-SP: Campinas, setembro, 2012.

BARROSO, J. R. Identidade coletivas e as cidades globais; triangulações com a cultura global. In. . (coord.) Globalização e identidade nacional. São Paulo: atlas, 1999.

BOBBIO, N. et alii. Dicionário de política. Brasília: Editora UNB, verbete Política, 1995.

BOURDIEU, Pierre. A economia das trocas simbólicas. 7 ed. São Paulo: Perspectiva, 2013. , Pierre. O Poder Simbólico.1989.

CANCLINI, Néstor Garcia. Consumidores e cidadãos: conflitos multiculturais da globalização. Rio de Janeiro: Editora UFRJ, 2006.

- Culturas Híbridas - estratégias para entrar e sair da modernidade. São Paulo: EDUSP, 1997.

CASTELLS, Manuel. O Poder da Identidade. São Paulo: Paz e Terra, 2000. FRIDMAN, F.. De núcleos coloniais a vilas e cidades: Nova Friburgo e Petrópolis. Anais: Encontros Nacionais da ANPUR, v. 9, 2013.

HALL, Stuart. A identidade cultural na pós-modernidade. 11.ed. Rio de Janeiro: DP\&A, 2011.

IANNI, Otávio. Teorias da globalização. 12. Ed. Rio de Janeiro: Civilização Brasileira, 2004.

GAGNEBIN, J. M. O rastro e a cicatriz: metáforas da memória. In: Lembrar escrever esquecer. São Paulo: editora 34, 2006, p. 107 - 118. 
GUPTA, Akhil; FERGUSON, James. Mais além da "cultura": espaço, identidade e política da diferença. O espaço da diferença. Campinas: Papirus, p. 30-49, 2000.

HUYSSEN, A. Seduzidos pela memória: arquitetura, monumentos, mídia. Rio de Janeiro: Aeroplano, 2000. (Capítulo 2)

LE GOFF, J. História e memória. Campinas: UNICAMP, 1996. (Capítulo Memória)

LORDEIRO, M. S. Toponímia petropolitana: uma situação preocupante. Disponivel emhttp://www.ihp.org.br/lib_ihp/docs/msl20010921.htm. Acessado em: 19/05/2014.

PEREIRA, A.P.L. O relato hagiográfico como fonte histórica. Revista do Mestrado de História, v. 9, n. 10, p. 161, 2007.

POLLAK, M. Memória, esquecimento, silêncio. Estudos Históricos, Rio de Janeiro, vol. 2. n. 3, 1989, p. 3-15.

. Memória e identidade social. Estudos Históricos, Rio de Janeiro, vol. 5. n. 10, 1992, p. 200-212.

ROBERTSON, R. Identidade nacional e globalização; falácias contemporâneas. In: BARROSO, J. R. (coord.) Globalização e identidade nacional. São Paulo: atlas, 1999.

SANTOS, Boavantura de Souza (org.). A globalização e as ciências sociais. - 2. ed. - São Paulo: Cortez, 2002.

SILVA, Tomaz Tadeu da (org). Identidade e diferença: a perspectiva dos Estudos Culturais. 12 ed. Petrópolis, RJ: Vozes, 2012.

SOUZA, B.C.P. de [etalli]. Geographical Names as a Cultural Expression: an Analysis of the City of Petrópolis - RJ, Brazil.

VELHO, Gilberto. Projeto metamorfose: antropologia das sociedades complexas. Rio de Janeiro: Zahar, 1994.

YÚDICE, George. A conveniência da cultura: usos da cultura na era global. Belo Horizonte: Editora UFMG, 2006. 615 p. 